\title{
Examining Technology for Teaching and Learning
}

\author{
Pamela A. Lemoine ${ }^{1}$, Robert E. Waller ${ }^{2}$, Christopher J. Garretson ${ }^{2} \&$ Michael D. Richardson ${ }^{3}$ \\ ${ }^{1}$ Troy University, USA \\ ${ }^{2}$ Columbus State University, USA \\ ${ }^{3}$ Global Tertiary Institute, USA \\ Correspondence: Michael D. Richardson, Global Tertiary Institute, Livingston, TN 38570, USA.
}

Received: June 7, 2020

Accepted: July 27, 2020

Online Published: August 3, 2020

doi:10.20849/jed.v4i2.781

URL: https://doi.org/10.20849/jed.v4i2.781

\begin{abstract}
Much time, money, and attention has been given to the issue of technology in the K-12 classroom. In addition, there is an ever-expanding interest in preparing students for success in a transforming, technology-rich world. In the 21st century technology and education must work together to secure the future for students and society. Society in the 21 st century is knowledge-based; learning is critical as knowledge resiliency continually becomes important for survival in the rapidly changing environment. The need for changing traditional approaches to education from the acquisition of short-term skills to proactive programs that infuses technology into the learning are of utmost importance as educators prepare students for the 21 st century.
\end{abstract}

Keywords: technology, learning, teachers, information age, accountability

\section{Introduction}

Albert Einstein once remarked that the world seems to be characterized by a proliferation of means and a confusion of goals (Einstein, 1950). If this can be said of the world in general, it certainly can be said of the world of K12 education (Goldin \& Katz, 2018). The age of technology and the information society are sweeping educators towards a future dependent upon knowing how to function in this new world. Education in the United States and around the world is reshaped daily with new technologies (An \& Mindrila, 2020). The use of 21st century technology in education is crucial as educators attempt to prepare 21 st century students for future jobs in a globally competitive and interactive digital workplace (Bocanet \& Fleseriu, 2020). Using information and communication technologies (ICT) is a 21 st-century skill that will continue to be in great demand (Erkulova, Samandarov, Samandarova, 2020).

Educators have historically been dispensers of information; however, in the current educational framework the exact opposite should be true - educators should be facilitators of knowledge acquisition. The need for changing traditional methods of education from reactionary approaches and the acquisition of short-term skills to proactive programs that necessitate life-long learning attitudes is of paramount importance as schools prepare students for the 21 st century (Crompton, Burke, \& Gregory, 2017). Therefore, an examination of the uses of technology by teachers in the K12 classroom is essential and important to educators and decision makers

\section{The Information Age}

The world is now in an information age, an age when knowledge doubles in little more than a year, and in an age when education's future will be determined by how well educators assimilate and use the new information (Harvey \& Marlatt, 2020). Many educators continue to operate from a traditional system of existing pedagogy, the dispensing of information. Advocates of educational change promote the need for a learning environment that prepares students to deal with changes as they occur, and optimistically, to help create needed changes (Heflin, Shewmaker, \& Nguyen, 2017). Some have suggested that the key to long-term success is resiliency, not sustainability. To address these concerns, many educators have turned to technology as a tool for increasing student achievement (Bibi \& Nawaz, 2020).

During the next decade, technical innovations will continue to alter the skills and knowledge needed to succeed in the workplace and society. Preparing technically educated and skilled individuals is of great economic importance to the world and requires significant attention from educators, policy-makers and employers (Brown \& Green, 2018). To keep pace with technological development, educators must assume a leadership role in 
optimizing the use of instructional technology. The leadership role should articulate the responsibility for technology not only for transferring knowledge but also for transforming learning. The need for technology integration has some asking whether the curriculum is driving technology usage, or is technology driving the curriculum (Rizk, 2020)?

Education provides students with the knowledge and skills necessary to function in society. Now that society has assumed a global focus, supported by technology, education institutions are asked to offer the highest quality education, especially technology literacy, to a widely diverse audience at a cost that can be supported by government (Orta, 2019). Educators should recognize the importance of incorporating technology into the delivery of instruction so that graduates can possess the skills required by a global, technical, information society (Vidal, 2020).

Throughout the world, educators are attempting to determine the impact of technology (Ghavofelr \& Rosdy, 2015). Standards for the utilization of technology in schools have been outlined by national organizations and accrediting agencies; educators are attempting to thrive and survive with the most current technologies as the increased development and application of technology has become a sociological phenomenon. However, the integration of technology for instructional uses has created a schizophrenic atmosphere for educators. Select, evaluate, implement, and be held accountable. What is the new technology challenge of the month (Howard \& Mozejko, 2015)?

Educational leaders and teachers are subjected to immense social, political and accountability pressures to improve educational opportunities for all students (Lynch, Ardito, \& Amendola, 2020). Curriculum reform, strengthening faculty qualifications, and increasing productivity are highly visible aspects of the current educational reality (Grimus, 2020). However, one of the most precious resources--time--must be conserved and managed to permit the efficient operation of educational institutions to improve educational results, particularly with regard to learning opportunities for students (Kolb, 2017). Technology assists teachers to utilize time more effectively and efficiently to increase additional learning opportunities for students. The availability of more effective and efficient computer systems means automation is reaching a point where more time is available for instructional concerns (Hall \& Trespalacios, 2019).

\section{The Infusion of Technology}

In recent years, evolving technologies have revolutionized teaching, creating a constantly changing environment for teachers. For example, educational technology can provide struggling, special needs, and non-English language students greater opportunities for success (Matsumoto, Shibata \& Hattori, 2020). Schools must no longer simply teach computer skills; digital technology must be embedded in the process of education, such that education itself is technologically mediated across the curriculum as a matter of necessity (Loyless \& Shaw, 2020). There is also an increasing tendency to use digital technologies for teaching and learning, monitoring, assessment, and recording purposes. The innovation of software being used in schools is shifting to ideas of adaptive curriculum based on personalized learning and continuous assessment (Olah, 2019).

The infusion of technology into educational practice created a paradigm shift within the educational system because the changes occurring within society drive technology use. The shift in learning is driven by technologies that rapidly became an integral part of society, which can empower the needs of the new generations of learners (Taber, 2017). For a significant change to be successful, like the introduction of technology into schools, educators must lead the way, regardless of mandates (Ames, 2017). Viewed broadly, technology can become a tool to revolutionize information processing, instructional delivery, and knowledge acquisition through teaching and learning (Razali, 2019).

Technology makes the business of education more complicated, competitive and comprehensive. Progressive technology management has been adopted in many schools as technology applications may be the only means by which both educational administrators and faculty manage the sheer volume of information necessary for success in today's technological environment. Technological changes are occurring at such an accelerating rate that the production of knowledge makes technology integration essential (Atman Uslu \& Usluel, 2019).

\section{Helping Teachers to Use Technology}

Technology, like all innovations, is only as efficient and effective as the person who uses it. Educators are teaching children how to live successfully in a future that is increasingly ambiguous and fast-paced. That is a formidable task for every teacher, but especially today for a teacher who may not be comfortable in the quickly changing world of technology (Carver, 2016). Today teachers are asked to make a paradigm shift; they are asked to teach students to think, but instead of imparting knowledge they now must help students understand where 
and how to find knowledge (DeCoito \& Richardson, 2018). Advancing and developing strong technical aptitudes with instructional technology can be a challenge for educators who are confronting a fast and indelible change to the technological tools they are expected to utilize for classroom instruction (Safitry, Mantoro, Ayu, Mayumi, Dewanti, \& Azmeela, 2015).

The reason is easily seen in the proliferation of knowledge so evident in this technological world. Teachers cannot keep up with everything in any field of knowledge (Mulyati, 2019). What was once learned as important today may be just a minor piece of knowledge tomorrow. Finding information as needed is as important, or more important, than knowing facts that may be obsolete in a short amount of time (Zinger, Tate, \& Warschauer, 2018). Exposing students to the wealth of information sources becomes the job of the teacher and that knowledge is available through the technology of today's world, particularly through the Internet (Semerci \& Aydin, 2018). Therefore, it becomes critical for teachers to understand the technology in order to use it in their classrooms and to make it available to their students (Thomas, 2020). There is indeed a proliferation of means.

\section{Technology and Student Learning}

Technology is becoming more deeply integrated into school curricula creating learning and innovation that empowers educators to enhance student learning through the infusion of contemporary technologies and digital learning (Filipe Matos, Pedro, \& Piedale, 2019). Technology is impacting student learning positively. Computers and all the technological innovations that are at an educator's disposal are just tools to help educators and students find and analyze information. These tools will be important to learning, not just because they are so prevalent, but because they can provide service to education and students (Harper, 2018). To use these tools appropriately, educators must move away from a "cookbook mentality" to a position of having a foundation in knowledge application. Technology is anticipated to play a key role in transforming education and training towards supporting deeper, higher-order learning (Howard, Chan, Mozejko \& Caputi, 2015). Educators must prepare students to be able to find the information they need, the knowledge about how to critically analyze what they find rather than simply to regurgitate facts (Anas, 2019).

Technology should not be an end for education; it should be the means to achieve the goals of education. This requires educators to use technology as a learning tool, to assist the learner with the task of learning (Belnap \& Parrott, 2020). Thus technology has the ability to transform the way educators teach in the coming decades and the way students learn. Drucker (1993) suggested that educators can learn lessons from an earlier technological revolution - the printed book. The lessons:

1. That embracing the new technology of learning and teaching is a prerequisite for national and culture success---and equally for economic competitiveness.

2. Technology itself matters less than the change which it triggers in substance, content and focus of schooling and school. (p. 194-195)

To be successful in a technology driven environment, educators must develop applications using technology to assist in the learning tasks of students (McKnight, O’Malley, Ruzic, Horsley, Franey, \& Bassett, 2016). Obviously, the complexity and the utilization of these applications will vary depending upon the expertise of the user. Students who live in the 21 st century need to know how to learn and technology can provide a valuable key (Leneway, 2018). If educators merely train students and give them a bag of tricks or skills, those skills may very well be outdated in six months given the rapid development of technology (Kennedy \& Ferdig, 2018).

What educators should be providing is experience in how to learn and helping students develop learning attitudes and attributes. If, in fact, employees learn most of what they know on the job, why should educators concentrate their attention on the acquisition of skills? Educators can effectively and efficiently give students the opportunities and knowledge about how to learn on the job and throughout life (Gane, Zaidi, \& Pellegrino, 2018). Education needs to shift from the acquisition of skills so prevalent in today's schools to a true learning mentality, to understand the complexities of current society and education's vital role in creating new learning opportunities. Technology can be an invaluable tool for student learning and instructional expertise for teachers is crucial (Sahoo, 2019).

Motivating student learning through technological resources for learning requires teachers to develop and use technological applications to assist in the learning tasks of students (Humble, Mozelius, \& Sallvin, 2019). The goal should be to find ways for technology to make teaching and learning more efficient and effective, not more complicated. A change in perspective, strength and usage of current and futuristic technologies seems to be inevitable (Tingir, Cavlazoglu, Caliskan, Koklu, \& Intepe-Tingir, 2017).

One of the acknowledged difficulties, however, is the need to provide appropriate professional development 
opportunities for teachers to become familiar with new technologies and learning applications inherent in technologies (Ibieta, Hinostroza, Labbe, \& Claro, 2017). Obtaining proper training is critical in teacher acceptance of technology learning because advancement in technology does not necessarily lead to effective teaching without teacher involvement. The best teaching practices depend on creative, well-informed instructors (Lawrence, Saran, Johnson, \& Lafontant, 2020). Teachers can become overwhelmed by the complexities of learning how to use technology effectively while at the same time trying to teach students the same skills. Second, teachers need guidance in formulating critical approaches that fit both the environment and needs of their schools (Mouza, 2019).

Digital technology has transformed learning and will continue to alter the design and delivery of instruction so teacher's learning of technology mediated instruction must involve continued professional development. Thus, the focus needs to be on flexibility, learning and development of new knowledge instead of specific solutions (Hall, Uribe-Florez, \& Rice, 2019). As information and communications technology continue to grow exponentially, educators feel constant pressures to adopt and maintain up-to-date technology competencies and simultaneously fight a never-ending battle against technology obsolescence (Sadaf, 2019).

\section{Opponents of Technology}

If the proliferation of technology means presents challenges, the other part of Einstein's statement is equally challenging, for there is indeed a confusion of goals prevalent in the world of K12 education. The rapid introduction of technology demands that teachers know and be able to use technology. Yet, that introduction is meeting resistance from some educators who cannot or do not want to adjust to the new reality of teaching (Hur, Shannon, \& Wolf, 2016).

In a real sense the past is meeting the future and many educators are being dragged into this new century instead of leading the way. Inquiry into the learning process, cognitive as well as affective, is a growing concern for education (Schuetz, Biancarosa, \& Goode, 2018). Some critics of public education argue that educators have done little to learn about teaching and learning; the instructional mode has scarcely changed over the past 50 years. The resources allocated to educational innovation are usually minuscule or non-existent and, in most cases, reduced funding is the flavor of the month.

There are two strong potential arguments against technology utilization in schools. The first is that technology will not save schools or teachers. Technology can be a positive but if a school does nothing else to improve instruction except provide infrastructure then educational experiences will not improve for students (Selwyn, 2016). Therefore, many teachers may still hold negative attitudes about the many different ideas and new modalities that districts are mandating them to deliver using new technological tools (Hsu, 2016). Improving instruction takes planning first and foremost so that everyone is working toward the same goal. Only then can technological innovations make positive differences in the classrooms.

The other argument concerns the effectiveness of the inclusion of technology. Despite years of integrating technology in education, there is still no way to measure that effectiveness. The impact of technology on the academic progress of the student is an unknown. While teachers can anecdotally note that students are "turned on" by the technology, and that they are involved in their learning, teachers cannot with certainty show that learning has increased because of the technology. Perhaps with more time to study the impact, technology can be shown to improve learning, but for now the effectiveness is only assumed, not proven (Davies, Nyland, Bodily, Chapman, Jones, \& Young, 2017).

Many teachers claim to use technology in the classroom; however, according to Elstad and Christophersen (2017), 56\% of students in a secondary class setting reported that their teachers did not know how to use the technology. Although many teachers do use some technology during the instructional day, much of the technology remains underutilized. Significant resources have been invested to integrate instructional technology; empirical evidence on the effect of technology on student outcomes is mixed (Fazal \& Bryant, 2019).

\section{Technology Accountability}

Accountability has been a concern for educators for as long as schools have existed; however, only recently has technology become a focus for accountability. Society is tied inextricably to education and education appears to be functionally coupled with technology. Like all governmental institutions, schools are accountable for their performance to the public (Delgado, Wardlow, McKnight, \& O'Malley, 2015). What is accountability? It is being responsible for the fulfillment of obligations - liable for being called to account for actions in the discharge of duties. Fulfilling the public's high expectations in the delivery of education is the key to public trust and confidence in schools. If the public perceives there is prompt, accurate, accessible, cost-effective, and fair service, 
public trust and confidence will be high and the school's absolutely critical role in society will be enhanced. And here technology has a vital role to play as more of society is "tuned in to technology" and expects the same from educators and schools (White \& Johnson, 2018).

The long-range purpose of accountability is to enhance productivity. Productivity is measured today by student performance. Internationally schools have been subjected to externally driven demands for accountability that have not proven to be effective. Often these demands have pressured educators to make decisions that have little or no application in the real world. Irrespective of the ineffectiveness, numerous countries have advocated strong external accountability without understanding the low organizational capacity of the educational instructions to deliver critical productivity (Dexter \& Richardson, 2020). The size of the continued accountability movement indicates that the survival of public education may very well hinge on the ability of educators to demonstrate productivity and accountability in a chaotic marketplace that is driven by technology; therefore, the utilization of technology in instruction helps give schools the evidence needed to make substantial changes to enhance productivity of the students and demonstrate accountability (Johnson, 2020).

\section{What Is an Educator to Do?}

With the growing push to implement innovative technologies in today's classroom, the prospect of digital learning has moved education into uncharted territory, creating dynamic learning experiences for students learning that is adaptive, personalized, and continuous is shown to produce significant results in both learner achievement and enjoyment of the learning process (Nikolopoulou, 2020).

Educators are attempting to survive a sociological phenomenon, the increased utilization and application of technology. When considering technology, knowledge is the center, the human is the soul and the information technology is just an auxiliary tool. As technical capabilities continue to increase, costs continue to decline, and educators improve their abilities to utilize the new technology tools, a new era of knowledge utilization appears imminent. In the wake of this increased technology all schools inherently store, access, and deliver knowledge in some manner (Bond \& Bedenlier, 2019). The question is what value is added to the products and services they deliver by the effective use of that knowledge capital through the use of technology, particularly when used in instructional delivery? Technology has a long and interesting history in schools, but never have the requirements for implementation and utilization been so great.

Education is becoming increasingly complex and it is facing unprecedented challenges. Managing changes in the field of education and improving it further is one of the most complex tasks of educators. Educators need to develop new processes and systems that will promote and encourage quality learning. Today, the education system must meet new standards of quality that are being demanded by an increasingly technological and diverse society. Like business and industry, educators are discovering that the old ways do not work, and that innovation is essential (Wilson, 2020).

The reaction of educators to technology should address five points. First, educators need to understand technology. All technology is not useful and beneficial; likewise, all technology is not useless. Educators must create and increase knowledge efficiency to enhance the organization and student learning by sharing knowledge derived from data and information generated in the school. This dissemination of knowledge will create the discovery and application of new knowledge to improve student success (Lindqvist, 2019).

Second, educators should use the strengths and abilities of others. They should find other educators or educational leaders who may know about the instructional applications of technology. Technology should not be feared but used, and teachers should make use of the capabilities of others who have knowledge about how to use technology. Perhaps the least obvious but potentially most important consequence of introducing technology is the change it will bring to the way faculty members do their work. But more significant will be the impact on the independence and autonomy of faculty members. There will be a greater need for teamwork, planning, and training, and at least in the short-term the use of technology is likely to require that much more time be spent and attention paid to teaching-related activities than has been the custom. Technology capability is much more to do with an approach to learning and working than simply a set of technological skills (Han, Han, \& Shin, 2019).

Third, technology should not be feared. Technology will not replace schools or teachers, only enhance them, but that will only occur when educators become less defensive and make plans to reinvent themselves and their schools. It is easy to recognize that educators should be focused on using information to obtain and disseminate knowledge to make quality instructional decisions, and not using isolated data. Schools are in a time of emergence when the best advice is to observe and to be sensitive to areas from which change is emerging. Periods of emergence are characterized by hype, hope, uncertainty, fear, risks, and opportunities; such should be the anticipation of teachers using technology for instruction (Georgiou \& Ioannou, 2019). 
Fourth, promote technology. Educators should demonstrate their commitment to technology use by their personal use of technology. They should also promote the effective and efficient use of technology with other faculty, staff, students and the community. The goal of educators should be to bring about change in their environments, from teaching facts to teaching how to learn. The educators who possess the capabilities to produce change should have a repertoire of possible actions they can perform in order to promote knowledge, to produce the desired results within the organization and to create a culture conducive for improvement of student teaching (Segal \& Heath, 2020).

Fifth, evaluate technology. Educators have historically failed to evaluate innovations in schools, which often leads to antiquated and misguided decisions and less than efficient use. As schools become increasingly aligned through standards, assessments and other measures, providing information about whether students are being successful in transitioning between education levels becomes critical. Longitudinal data on student courses and grades test scores and remediation rates also can serve as indicators of student learning. Evaluating the contribution of technology to learning is a critical key to success (Tondeur, van Braak, Ertmer, Ottenbreit-Leftwich, 2017).

\section{Implications}

Technology is often viewed as hard-ware or soft-ware, but it is also a philosophy for improving learning. Without knowledge about technology and the use of technology students will be at a major disadvantage in the future.

\section{Conclusions}

(1) Technology is reshaping teaching and learning.

(2) Personalizing instructional delivery through the strategic use of technology is a key part of teaching and learning.

(3) The primary goal of schools is to increase learning for each student; therefore, it is imperative that effective resources are utilized appropriately to aid teachers in meeting the educational needs of all students despite the wide variations of students that can exist in a single classroom.

(4) Being adaptable in a dynamic world, knowing how to 'learn how to learn,' will be one of the most important assets any educator can have to be successful in the application and utilization of technology for enhanced student learning.

(5) New techniques and procedures for evaluating technology use in teaching and learning are continually improving.

\section{References}

Ames, C. W. (2017). Teacher perceptions of factors influencing technology integration in k-12 schools. Master's thesis, Utah State University, Logan, UT.

An, Y., \& Mindrila, D. (2020). Strategies and tools used for learner-centered instruction. International Journal of Technology in Education and Science (IJTES), 4(2), 133- 143. https://doi.org/10.46328/ijtes.v4i2.74

Anas, I. (2019). Educational technology and teacher-student technology competency: A pathway to teaching English with Technology. Journal of English Language Teaching and Linguistics, 4(2), 181-191. https://doi.org/10.21462/jeltl.v4i2.270

Atman Uslu, N., \& Usluel, Y. K. (2019). Predicting technology integration based on a conceptual framework for ICT use in education. Technology, Pedagogy and Education, 28(5), 517-531. https://doi.org/10.1080/1475939X.2019.1668293

Belnap, J. K., \& Parrott, A. (2020). Putting technology in its place. Mathematics Teacher: Learning and Teaching PK-12, 113(2), 140-146. https://doi.org/10.5951/MTLT.2019.0073

Bibi, S., \& Nawaz, M. H. (2020). A study on the effect of emerging technology on students' academic achievements at secondary level. Journal of Business and Social Review in Emerging Economies, 6(1), 365-378. https://doi.org/10.26710/jbsee.v6i1.1088

Bocanet, V. I., \& Fleseriu, C. (2020). Modern technologies used in education. In Developing technology mediation in learning environments (pp. 190-205). Hershey, PA: IGI Global. https://doi.org/10.4018/978-1-7998-1591-4.ch011

Bond, M., \& Bedenlier, S. (2019). Facilitating student engagement through educational technology: Towards a 
conceptual framework. Journal of Interactive Media in Education, 2019(1), 12. https://doi.org/10.5334/jime.528

Brown, A., \& Green, T. (2018). Issues and trends in instructional technology: Consistent growth in online learning, digital content, and the use of mobile technologies. In Educational Media and Technology Yearbook (pp. 61-71). Cham, Switzerland: Springer. https://doi.org/10.1007/978-3-319-67301-1_5

Carver, L. B. (2016). Teacher perception of barriers and benefits in K-12 technology usage. Turkish Online Journal of Educational Technology-TOJET, 15(1), 110-116. https://doi.org/10.21125/inted.2016.1845

Crompton, H., Burke, D., \& Gregory, K. H. (2017). The use of mobile learning in PK-12 education: A systematic review. Computers \& Education, 110, 51-63. https://doi.org/10.1016/j.compedu.2017.03.013

Davies, R., Nyland, R., Bodily, R., Chapman, J., Jones, B., \& Young, J. (2017). Designing technology-enabled instruction to utilize learning analytics. TechTrends, 61(2), 155-161. https://doi.org/10.1007/s11528-016-0131-7

DeCoito, I., \& Richardson, T. (2018). Teachers and technology: Present practice and future directions. Contemporary Issues in Technology and Teacher Education, 18(2), 362-378.

Delgado, A. J., Wardlow, L., McKnight, K., \& O’Malley, K. (2015). Educational technology: A review of the integration, resources, and effectiveness of technology in K-12 classrooms. Journal of Information Technology Education, 14, 397-416. https://doi.org/10.28945/2298

Dexter, S., \& Richardson, J. W. (2020). What does technology integration research tell us about the leadership of technology?. Journal of Research on Technology in Education, 52(1), 17-36. https://doi.org/10.1080/15391523.2019.1668316

Drucker, P. F. (1993). The rise of the knowledge society. Wilson Quarterly, 93(17), 52-70. https://doi.org/10.1016/B978-0-7506-0921-0.50006-9

Einstein, A. (1950). Out of my later years. London, UK: Thames and Hudson. https://doi.org/10.1097/00010694-195006000-00011

Elstad, E., \& Christophersen, K. (2017). Perceptions of digital competency among student teachers: Contributing to the development of student teachers' instructional self-efficacy in technology-rich classrooms. Education Sciences, 7(1). https://doi.org/10.3390/educsci7010027

Erkulova, F., Samandarov, U., \& Samandarova, G. (2020). The use of ICT in teaching English grammar in secondary schools. International Journal on Integrated Education, 3(1), 129-131. https://doi.org/10.31149/ijie.v3i1.297

Fazal, M., \& Bryant, M. (2019). Blended learning in middle school math: The question of effectiveness. Journal of Online Learning Research, 5(1), 49-64.

Filipe Matos, J., Pedro, A., \& Piedade, J. (2019). Integrating digital technology in the school curriculum. International Journal of Emerging Technologies in Learning, $14(21)$. https://doi.org/10.3991/ijet.v14i21.10863

Gane, B. D., Zaidi, S. Z., \& Pellegrino, J. W. (2018). Measuring what matters: Using technology to assess multidimensional learning. European Journal of Education, 53(2), 176-187. https://doi.org/10.1111/ejed.12269

Georgiou, Y., \& Ioannou, A. (2019). Teachers' concerns about adopting technology-enhanced embodied learning and their mitigation through professional development. Journal of Technology and Teacher Education, 27(3), 335-371.

Ghavifekr, S., \& Rosdy, W. A. W. (2015). Teaching and learning with technology: Effectiveness of ICT integration in schools. International Journal of Research in Education and Science (IJRES), 1(2), 175-191. https://doi.org/10.21890/ijres.23596

Goldin, C., \& Katz, L. F. (2018). The race between education and technology. In D. B. Grusky, \& J. Hill (Eds.), Inequality in the 21st Century (pp. 49-54). New York, NY: Routledge. https://doi.org/10.4324/9780429499821-10

Grimus, M. (2020). Emerging technologies: Impacting learning, pedagogy and curriculum development. In Emerging technologies and pedagogies in the curriculum (pp. 127-151). Singapore: Springer. https://doi.org/10.1007/978-981-15-0618-5_8 
Hall, A. B., \& Trespalacios, J. (2019). Personalized professional learning and teacher self-efficacy for integrating technology in K-12 classrooms. Journal of Digital Learning in Teacher Education, 35(4), 221-235. https://doi.org/10.1080/21532974.2019.1647579

Hall, A., Uribe-Flórez, L., \& Rice, K. (2019). Studying teachers' self-efficacy and experience while empowering technology use through personalized professional learning. Journal of Technology and Teacher Education, 27(3), 373-413.

Han, I., Han, S., \& Shin, W. S. (2019). Teachers' and students' perspectives on good teaching using technology in elementary classrooms. International Journal of Information and Communication Technology Education (IJICTE), 15(3), 103-116. https://doi.org/10.4018/IJICTE.2019070108

Harper, B. (2018). Technology and teacher-student interactions: A review of empirical research. Journal of Research on Technology in Education, 50(3), 214-225. https://doi.org/10.1080/15391523.2018.1450690

Harvey, M. M., \& Marlatt, R. (2020). That was then, this is now: Literacy for the 21 st Century student. In Examining the roles of teachers and students in mastering new technologies (pp. 164-183). Hershey, PA: IGI Global. https://doi.org/10.4018/978-1-7998-2104-5.ch008

Heflin, H., Shewmaker, J., \& Nguyen, J. (2017). Impact of mobile technology on student attitudes, engagement, and learning. Computers \& Education, 107, 91-99. https://doi.org/10.1016/j.compedu.2017.01.006

Howard, S. K., \& Mozejko, A. (2015). Teachers: Technology, change and resistance. In M. Henderson, \& G. Romeo (Eds.), Teaching and digital technologies: Big issues and critical questions (pp. 307-317). Port Melbourne, Australia: Cambridge University Press. https://doi.org/10.1016/j.compedu.2015.09.008

Howard, S. K., Chan, A., Mozejko, A., \& Caputi, P. (2015). Technology practices: Confirmatory factor analysis and exploration of teachers' technology integration in subject areas. Computers \& Education, 90(1), 24-35.

Hsu, P. (2016). Examining current beliefs, practices and barriers about technology integration: A case study. TechTrends, 60(1), 30-40. https://doi.org/10.1007/s11528-015-0014-3

Humble, N., Mozelius, P., \& Sällvin, L. (2019). Teacher challenges and choice of programming tools for teaching k-12 technology and mathematics. In M. Carmo (Ed.), Education and new developments (END2019) (pp. 431-435). Porto, Portugal: inScience Press. https://doi.org/10.36315/2019v1end099

Hur, J. W., Shannon, D., \& Wolf, S. (2016). An investigation of relationships between internal and external factors affecting technology integration in classrooms. Journal of Digital Learning in Teacher Education, 32(3), 105-114. https://doi.org/10.1080/21532974.2016.1169959

Ibieta, A., Hinostroza, J. E., Labbe, C., \& Claro, M. (2017). The role of the internet in teachers' professional practice: Activities and factors associated with teacher use of ICT inside and outside the classroom. Technology, Pedagogy and Education, 26(4), 425-438. https://doi.org/10.1080/1475939X.2017.1296489

Johnson, M. L. (2020). Teaching and tech: An investigation of the relationship and use of digital technologies and the overall effectiveness of the classroom learning environment. Peabody Journal of Education, 95(2), 183-192. https://doi.org/10.1080/0161956X.2020.1745609

Kennedy, K., \& Ferdig, R. E. (Eds.) (2018). Handbook of research of k12 online and blended learning (2nd ed.). Pittsburgh, PA: Carnegie Mellon University: ETC Press.

Kolb, L. (2017). Learning first, technology second: The educator's guide to designing authentic lessons. Portland, OR: International Society for Technology in Education.

Lawrence, S. A., Saran, R., Johnson, T., \& Lafontant, M. (2020). Preparing 21st Century teachers: Supporting digital literacy and technology integration in $\mathrm{p} 6$ classrooms. In Participatory literacy practices for $p-12$ classrooms in the digital age (pp. 140-162). Hershey, PA: IGI Global. https://doi.org/10.4018/978-1-7998-0000-2.ch008

Leneway, R. J. (2018). Transforming K-12 classrooms with digital technology: A look at what works!. In Information and technology literacy: Concepts, methodologies, tools, and applications (pp. 1506-1530). Hershey, PA: IGI Global. https://doi.org/10.4018/978-1-5225-3417-4.ch078

Lindqvist, M. H. (2019). Conditions for teaching with mobile technology in the school classroom. In Emergent practices and material conditions in learning and teaching with technologies (pp. 69-87). Cham, Switzerland: Springer. https://doi.org/10.1007/978-3-030-10764-2_5

Loyless, S. D., \& Shaw, E. C. (2020). Beyond retreat and rebellion: Building teacher capacity for optimized 
student engagement and agency. In Leveraging technology to improve school safety and student wellbeing (pp. 227-243). Hershey, PA: IGI Global. https://doi.org/10.4018/978-1-7998-1766-6.ch013

Lynch, T. L., Ardito, G., \& Amendola, P. (2020). Integrating computer science across the core: Strategies for k-12 districts. New York, NY: Eye on Education. https://doi.org/10.4324/9780429243783

Matsumoto, S., Shibata, K., \& Hattori, A. (2020). Mobile technology of learning and communication for students with disabilities. In Handbook of research on software for gifted and talented school activities in $k-12$ classrooms (pp. 265-281). Hershey, PA: IGI Global. https://doi.org/10.4018/978-1-7998-1400-9.ch012

McKnight, K., O'Malley, K., Ruzic, R., Horsley, M. K., Franey, J. J., \& Bassett, K. (2016). Teaching in a digital age: How educators use technology to improve student learning. Journal of Research on Technology in Education, 48(3), 194-211. https://doi.org/10.1080/15391523.2016.1175856

Mouza, C. (2019). Beliefs, models, and practices on fostering teacher learning in technology integration. Contemporary Issues in Technology and Teacher Education, 19(3), 302-304.

Mulyati, T. (2019). Teachers' reflection: Does the instructional technology implementation transform learning?. Ethical Lingua: Journal of Language Teaching and Literature, 6(1), 1-12. https://doi.org/10.30605/ethicallingua.v6i1.1115

Nikolopoulou, K. (2020). Secondary education teachers' perceptions of mobile phone and tablet use in classrooms: Benefits, constraints and concerns. Journal of Computers in Education, 7(2), 257-275. https://doi.org/10.1007/s40692-020-00156-7

Olah, D. A. (2019). Technology tools for integration in the classroom. In Faculty roles and changing expectations in the new age (pp. 101-114). Hershey, PA: IGI Global. https://doi.org/10.4018/978-1-5225-7438-5.ch007

Orta, N. (2019, November). Implementing learning technologies in schools: The role of organizational development and change management. In E-Learn: World conference on e-learning in corporate, government, healthcare, and higher education (pp. 208-213). Chesapeake, VA: Association for the Advancement of Computing in Education (AACE).

Razali, H. A. M. (2019). Pedagogy 21st Century from perspective information and communication technology (ICT): The application in learning. International Journal of Science and Applied Science: Conference Series, 3(1), 56-62. https://doi.org/10.20961/ijsascs.v3i1.32480

Rizk, J. (2020). Considerations for implementing emerging technologies and innovative pedagogies in twenty-first-century classrooms. In Emerging technologies and pedagogies in the curriculum (pp. 447-460). Singapore: Springer. https://doi.org/10.1007/978-981-15-0618-5_26

Sadaf, A. (2019). Exploring teachers' value beliefs of integrating digital literacy in K-12 classrooms. International Journal of Digital Literacy and Digital Competence (IJDLDC), 10(2), 1-14. https://doi.org/10.4018/IJDLDC.2019040101

Safitry, T. S., Mantoro, T., Ayu, M. A., Mayumi, I., Dewanti, R., \& Azmeela, S. (2015). Teachers' perspectives and practices in applying technology to enhance learning in the classroom. International Journal of Emerging Technologies in Learning, 10(3). https://doi.org/10.3991/ijet.v10i3.4356

Sahoo, R. K. (2019). Exploring the changes in teaching strategies enabled by information and communication technology. International Journal of Theory and Application in Elementary and Secondary School Education, 1(2), 66-80. https://doi.org/10.31098/ijtaese.v1i2.34

Schuetz, R. L., Biancarosa, G., \& Goode, J. (2018). Is technology the answer? Investigating students' engagement in math. Journal of Research on Technology in Education, 50(4), 318-332. https://doi.org/10.1080/15391523.2018.1490937

Segal, P., \& Heath, M. (2020). The "wicked problem" of technology and teacher education: Examining teacher educator technology competencies in a field-based literacy methods course. Journal of Digital Learning in Teacher Education, 36(3), 185-200. https://doi.org/10.1080/21532974.2020.1753600

Selwyn, N. (2016). Is technology good for education?. Cambridge, UK: Polity Press.

Semerci, A., \& Aydin, M. K. (2018). Examining high school teachers' attitudes towards ICT use in education. International Journal of Progressive Education, 14(2), 93-105. https://doi.org/10.29329/ijpe.2018.139.7

Taber, K. S. (2017). The role of new educational technology in teaching and learning: A constructivist 
perspective on digital learning. In A. Marcus-Quinn, \& T. Hourigan (Eds.), Handbook on digital learning for K-12 schools (pp. 397-412). Singapore: Springer. https://doi.org/10.1007/978-3-319-33808-8_24

Thomas, C. E. (2020). Teacher and student experiences in learning. Pacific Journal of Technology Enhanced Learning, 2(1), 3-13. https://doi.org/10.24135/pjtel.v2i1.21

Tingir, S., Cavlazoglu, B., Caliskan, O., Koklu, O., \& Intepe-Tingir, S. (2017). Effects of mobile devices on K-12 students' achievement: A meta-analysis. Journal of Computer Assisted Learning, 33(4), 355-369. https://doi.org/10.1111/jcal.12184

Tondeur, J., Van Braak, J., Ertmer, P. A., \& Ottenbreit-Leftwich, A. (2017). Understanding the relationship between teachers' pedagogical beliefs and technology use in education: A systematic review of qualitative evidence. Educational Technology Research and Development, 65(3), 555-575. https://doi.org/10.1007/s11423-016-9481-2

Vidal, D. (2020). From dysfunction to innovation in technology: Overcoming critical infrastructure and organizational dynamics in education. Lanham, MD: Rowman \& Littlefield Publishers.

White, C. C., \& Johnson, J. (2018). Change management in k-12 education for data-driven decisions: Moving from professional judgment to evidence. In Data leadership for K-12 schools in a time of accountability (pp. 54-74). Hershey, PA: IGI Global. https://doi.org/10.4018/978-1-5225-3188-3.ch004

Wilson, N. C. (2020). New barriers to technology integration and digital education equity: Fostering agency and engagement in technology-based activities. In Next generation digital tools and applications for teaching and learning enhancement (pp. 122-136). Hershey, PA: IGI Global. https://doi.org/10.4018/978-1-7998-1770-3.ch007

Zinger, D., Tate, T., \& Warschauer, M. (2018). Learning and teaching with technology: Technological pedagogy and teacher practice. In The SAGE Handbook of Research on Teacher Education (pp. 577-593). Thousand Oaks, CA: SAGE. https://doi.org/10.4135/9781526402042.n33

\section{Copyrights}

Copyright for this article is retained by the author(s), with first publication rights granted to the journal.

This is an open-access article distributed under the terms and conditions of the Creative Commons Attribution license (http://creativecommons.org/licenses/by/4.0/). 